\title{
Study on removal of typical pollutants in landfill leachate using two kinds of aquatic plant
}

\author{
Ying Bo, Pan Hongbo \\ ${ }^{1}$ Liaoning Environmental monitoring and experiment center, Shenyang, China, 110161 \\ winner4321@163.com
}

\begin{abstract}
Keywords: landfill leachate; Eichhornia crassipes; Pistia stratiotes; Purification effect
Abstract: In the static conditions, experiments were carried out to study the purification ability of Eichhornia crassipes and Pistia stratiotes from varying concentrations of landfill leachate. The results show that Eichhornia crassipes and Pistia stratiotes were poisoned to death completely in high concentration of landfill leachate (COD more than $1200.0 \mathrm{mg} \cdot \mathrm{L}^{-1}$ ) and survived in medium concentration of landfill leachate (COD $\left.560.0 \mathrm{mg} \cdot \mathrm{L}^{-1}-860.0 \mathrm{mg} \cdot \mathrm{L}^{-1}\right)$. In low concentration of landfill leachate (COD less than $660.0 \mathrm{mg} \cdot \mathrm{L}^{-1}$ ), the plants grew properly and purified landfill leachate effectively. After 24 days, the $\mathrm{COD}, \mathrm{TP}$ and $\mathrm{NH}_{3}-\mathrm{N}$ attained national standard of "Pollution control standard for life rubbish landfill (GB16889-2008)".
\end{abstract}

\section{Introduction}

The landfill leachate, as a secondary pollutants produced by sanitary landfill, contains a variety of toxic and hazardous substances. It would pollute the water and soil environment seriously if not handled properly. landfill leachate treatment has become a major national concerning environmental problems. With the development of rural economy, rural solid waste production increased year by year. Subjecting to the constraints of impervious ability, the leachate will affect the physical and chemical properties of surrounding surface water, groundwater, and even farmland near the refuse landfill. A suitable treatment of landfill leachate needs to be researched to purify the landfill leachate. Among the various repair methods, the phytoremediation technology has the advantage of low energy consumption, high detergent power, and small investment and easy operating, especially, the removal efficiency of organic compounds and heavy metals on phytoremediation are effectual.

\section{Materials and methods}

Experimental materials

The Eichhornia crassipes and Pistia stratiotes were bought from Shenyang flowers and birds market. Landfill leachate was acquired in Qingyuan county of Liaoning province.

In the static conditions, experiments were carried out in greenhouse base of Shenyang Agricultural University, lasted from October 28, 2015 to November 21. During the test, the indoor temperature kept for 15 to $20^{\circ} \mathrm{C}$. pH: Determined by acidimeter; COD: Determined by dichromate method; $\mathrm{NH}_{3}-\mathrm{N}$ : Determined by Nessler's reagent colorimetry; TP: Determined by Mo-Sb colorimetry.

\section{Experimental design}

The research showed that the Eichhornia crassipes and Pistia stratiotes behaved diverse tolerance ability of $\mathrm{COD}$ and $\mathrm{NH}_{3}-\mathrm{N}$ in different environment condition. In the meanwhile the landfill leachate contains complicated pollutant, so the experiment considered it first to study stain resistance of Eichhornia crassipes and Pistia stratiotes. Taking the COD as a pollution factor, landfill leachate was diluted to five kinds of concentration levels namely 2 times $\left(1720.3 \mathrm{mg} \cdot \mathrm{L}^{-1}\right), 3$ times $\left(1233.3 \mathrm{mg} \cdot \mathrm{L}^{-1}\right)$, 4 times $\left(860 \mathrm{mg} \cdot \mathrm{L}^{-1}\right), 5$ times $\left(660 \mathrm{mg} \bullet \mathrm{L}^{-1}\right)$ and 6 times $\left(560 \mathrm{mg} \cdot \mathrm{L}^{-1}\right)$, in order to observe the two plants' growth in varying concentration levels of landfill leachate and study the purification effect of the two plants that existed in suitable concentration levels of landfill leachate. 
Test devices were plastic containers of $4 \mathrm{~L}$ and the volume of landfill leachate in each device was 3L. The treatment of Eichhornia crassipes and Pistia stratiotes were marked as F treatments and D treatments. In the $\mathrm{CK}$ treatments that set respectively corresponding to the five kinds of concentration levels of landfill leachate, white foam was set in the plastic containers to simulate the overspread of the plants. The experiment set 3 replications. Pollutants concentration in varying concentrations of landfill leachate was shown in Table 1.

Table 1. The pollutants concentration in varying concentrations of landfill leachate $\left(\mathrm{mg} \cdot \mathrm{L}^{-1}\right)$

\begin{tabular}{ccccccc}
\hline Water quality index & $\mathrm{pH}$ & $\mathrm{COD}$ & $\mathrm{NH}_{3}-\mathrm{N}$ & $\mathrm{NO}_{3}-\mathrm{N}$ & $\mathrm{NO}_{2}-\mathrm{N}$ & $\mathrm{TP}$ \\
\hline Stock solution & 9.44 & 3546.7 & 527.5 & 7.62 & 5.07 & 8.02 \\
Diluted 2 times & 9.25 & 1720.3 & 259.6 & 3.75 & 2.49 & 4.21 \\
Diluted 3 times & 8.71 & 1233.3 & 182.9 & 2.49 & 1.62 & 2.83 \\
Diluted 4 times & 8.75 & 860.0 & 128.2 & 1.75 & 1.23 & 2.58 \\
Diluted 5 times & 8.70 & 660.0 & 99.7 & 1.53 & 0.99 & 1.59 \\
Diluted 6 times & 8.55 & 560.0 & 88.0 & 1.25 & 0.82 & 1.53 \\
\hline
\end{tabular}

\section{Results and discussion}

Growth of Two Plants in Varying Concentration Levels of Landfill Leachate

The two kinds of plants were present certain poisoning symptoms such as blight and staleness in every treatment after 3 days. Stem and leaf of the most plants droop and turned black in landfill leachate of high COD level (more than $1200.0 \mathrm{mg} \cdot \mathrm{L}^{-1}$ ). In medium concentration of landfill leachate (COD $560.0 \mathrm{mg} \cdot \mathrm{L}^{-1}-860.0 \mathrm{mg} \cdot \mathrm{L}^{-1}$ ), most of plants survived and had symptoms of illness. A Few of plants put up blight in the conditions of low COD level (less than $660.0 \mathrm{mg} \cdot \mathrm{L}^{-1}$ ). After 6 days, the Eichhornia crassipes and Pistia stratiotes were totally killed in the conditions of high COD level (Diluted 2 and 3 times). With the gradual degradation of pollutants in landfill leachate, a number of plants survived in the middle COD level (Diluted 4 times). In the condition of low COD level (Diluted 5 and 6times), both the Eichhornia crassipes and Pistia stratiotes grew lush, of which the biomass increased substantially. The experiment preceded in the landfill leachate diluted 5times. After 24 days, biomass of the F treatment and D treatment increased $145.93 \%$ and $80.53 \%$ respectively. The changes of biomass in landfill leachate of low concentrations were shown in Fig.1.

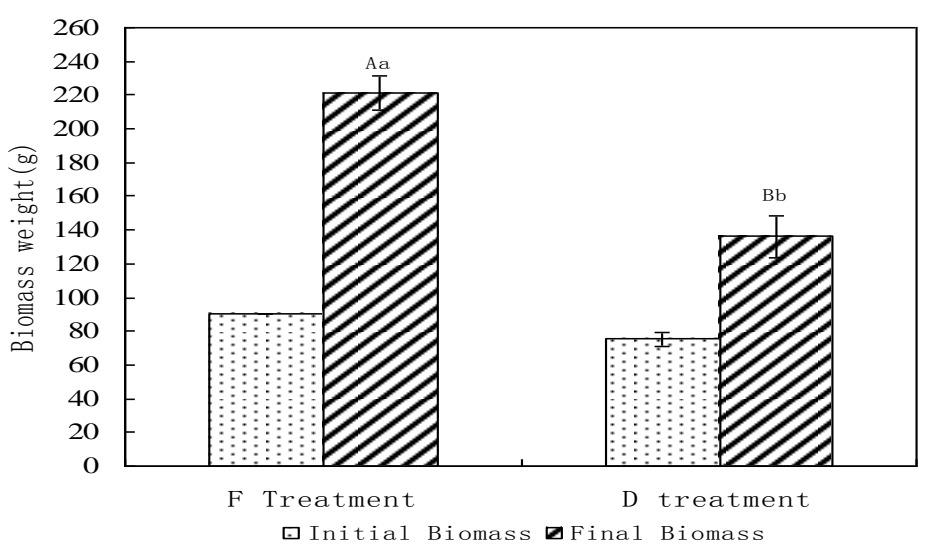

Fig.1 The changes of biomass in landfill leachate of low concentrations

Purification of COD in Landfill Leachate of Low Concentrations

The removal rates of COD in low concentration of landfill leach ate were shown in Fig.2. There was a obvious trend that removal rate is increasing gradually with the decreasing of the COD concentration. As a result of the dead plant residue which broke down more organics to the leachate, the content of COD fluctuated on the first 6 days. After 9 days, the removal rate of COD began to rise gradually in the 3 kinds of treatments. It's worth studying the relatively gentle process between 9 days to 15 days in which removal rates decreased slowly. Both the organics disintegrated by plant residue 
and negative acts from roots of saturation adsorption may contribute to it. After 15 days, the regenerate plants continue to take responsibility to adsorb COD. After 24 days, the removal rate of F, D and CK
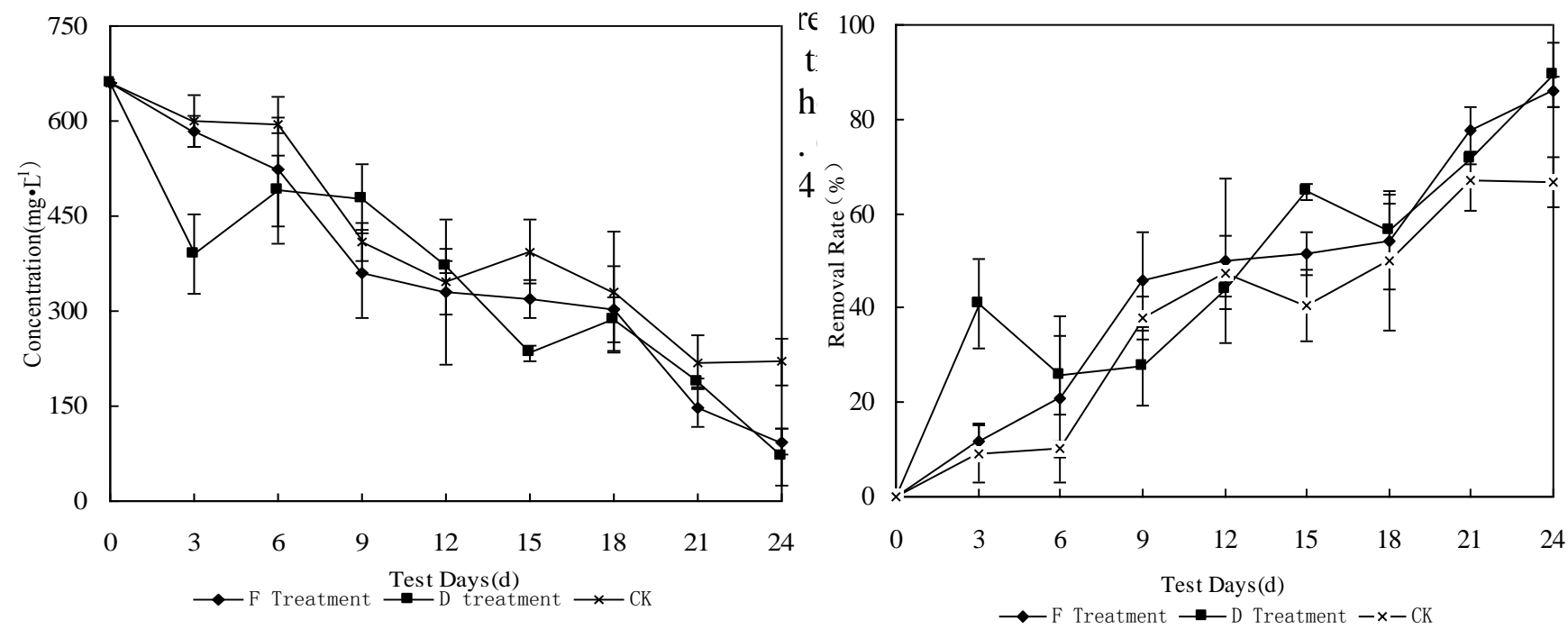

Fig.2 The changes of concentrations and removal rates of COD in low concentration of landfill leachat Purification of $\mathrm{NH}_{3}-\mathrm{N}$ in Landfill Leachate of Low Concentrations

Similar to the trend of COD removal process, $\mathrm{NH}_{3}-\mathrm{N}$ concentration decreased day by day with the increasing of removal rate was observed in Fig.3. $\mathrm{NH}_{3}-\mathrm{N}$ content attained national standard of "Pollution control standard for life rubbish landfill (GB16889-2008)" both in F and D treatments only within 6 days, comparing with 12 days' time-consuming in $\mathrm{CK}$ treatments. After 24 days, the $\mathrm{NH}_{3}-\mathrm{N}$ concentration of F, D and CK treatment was $0.03 \mathrm{mg} \cdot \mathrm{L}^{-1}, 0.40 \mathrm{mg} \cdot \mathrm{L}^{-1}$ and $0.17 \mathrm{mg} \bullet \mathrm{L}^{-1}$ respectively, the removal rate attained $99 \%$ in all treatments. The purifying capacity of $\mathrm{NH}_{3}-\mathrm{N}$ was presented in ascending order: $\mathrm{CK}<\mathrm{D}$ treatment $<\mathrm{F}$ treatment.

Plants absorb nitrogen mainly through ammonium and nitrate forms, also a few of micromolecule organics such as carbamide and amino acid. Generally speaking, the increasing biomass was associated with Nitrogen accumulation conducted in the plants (Jiang yue, 2004). In the static conditions of low landfill leachate content, the parts of increased biomass plants absorb the nitrogen better because less role stress was produced by the pollutant of landfill leachate.
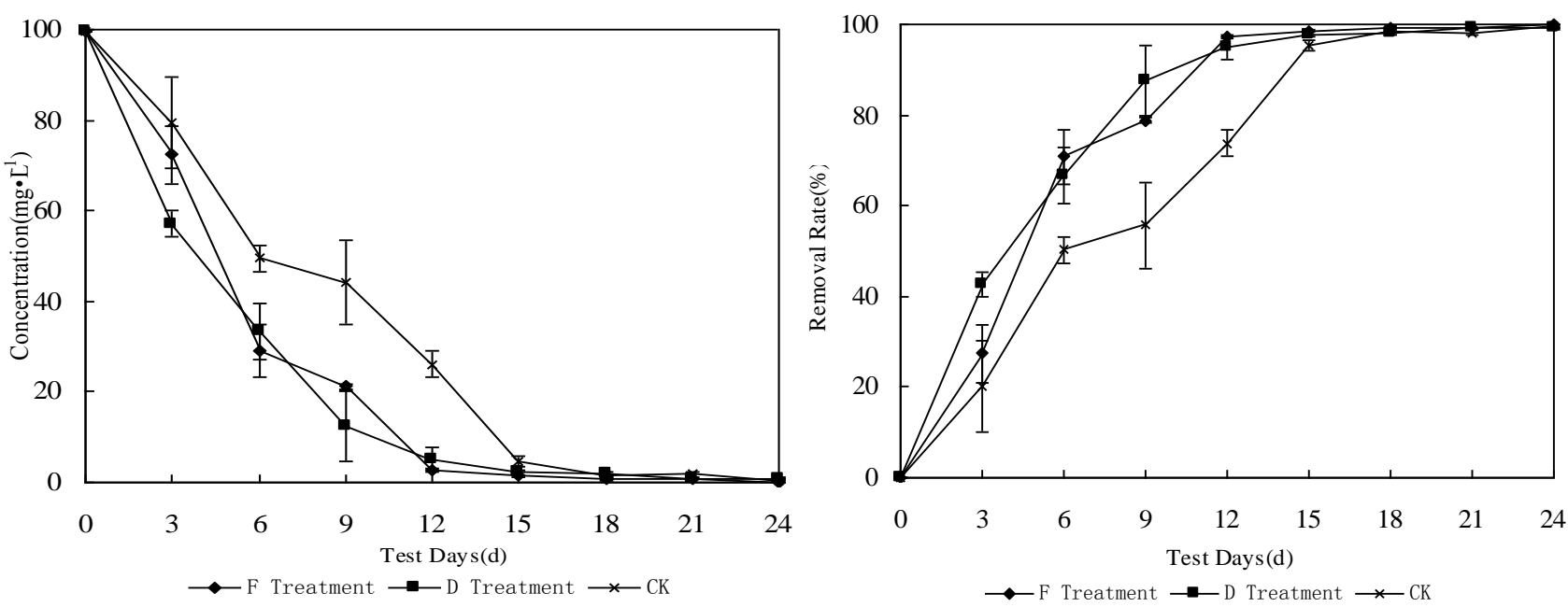

Fig.3 The changes of concentrations and removal rates of $\mathrm{NH}_{3}-\mathrm{N}$ in low concentration of landfill leachate Purification of Total Phosphorusin in Landfill Leachate of Low Concentrations

It is obvious that downward trend fluctuated on the first 12 days as a result of the increased phosphorus content decomposed by the rotten stem in Fig.4. After 24 days, the TP concentration of F, $\mathrm{D}$ and $\mathrm{CK}$ treatment was $0.17 \mathrm{mg} \cdot \mathrm{L}^{-1}, 0.51 \mathrm{mg} \cdot \mathrm{L}^{-1}$ and $0.80 \mathrm{mg} \cdot \mathrm{L}^{-1}$ respectively, the removal rate was 98.45\%, 98.98\% and 93.95\% respectively. Variance analysis showed the difference between F or D treatments with $\mathrm{CK}$ treatment reached significant levels $(\mathrm{P}<0.05)$. The purifying capacity of TP was 
presented in ascending order: $\mathrm{CK}<\mathrm{F}$ treatment $<\mathrm{D}$ treatment. Normally, a fraction of phosphorus in the waste water could be absorbed by the plants directly and transform to organic components as ATP, DNA and RNA, the remainings that absorbed by root system was available after microorganism's decomposition. Plant biomass and phosphorus uptake had positive significance correlation. In this experiment, it was clearly the absorption and utilization of phosphorusin by Eichhornia crassipes and Pistia stratiotes was the main wav of removing phosphorus in the waste water.
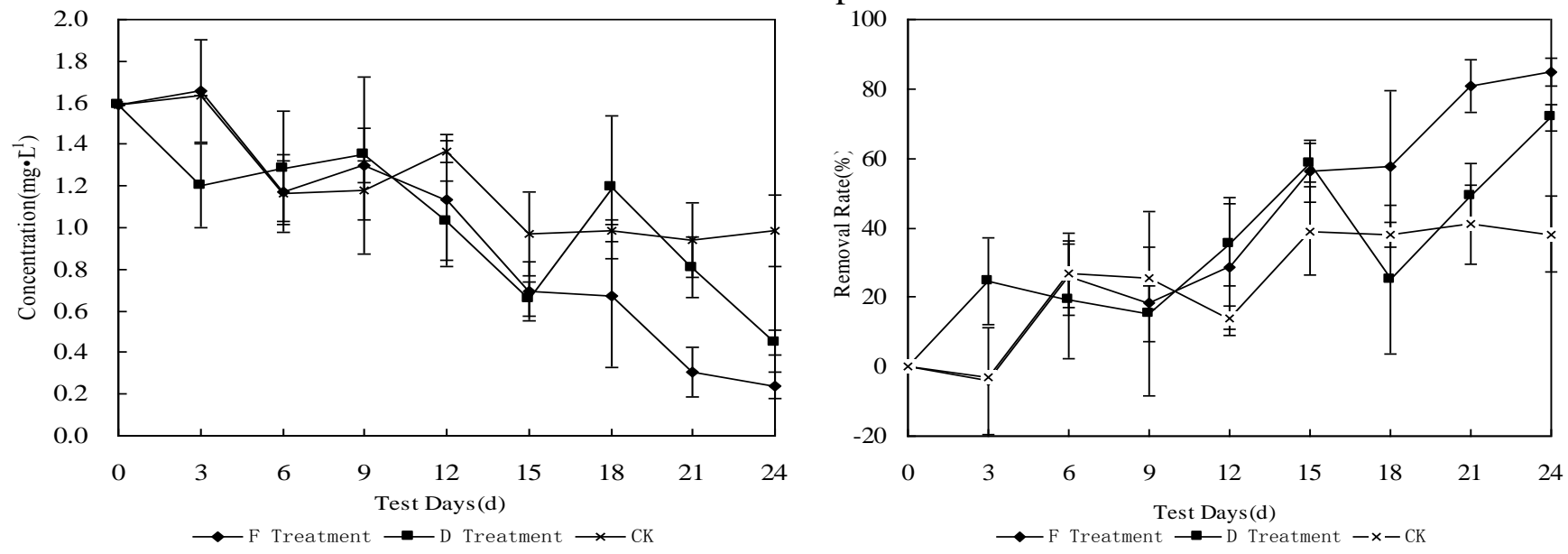

Fig.4 The changes of concentrations and removal rates of TP in low concentration of landfill leachate

\section{Conclusion}

(1) Eichhornia crassipes and Pistia stratiotes were poisoned to death completely in high concentration of landfill leachate (COD more than $1200.0 \mathrm{mg} \cdot \mathrm{L}^{-1}$ ) and survived in medium concentration of landfill leachate (COD $\left.560.0 \mathrm{mg} \cdot \mathrm{L}^{-1}-860.0 \mathrm{mg} \cdot \mathrm{L}^{-1}\right)$. In low concentration of landfill leachate (COD less than $660.0 \mathrm{mg} \cdot \mathrm{L}^{-1}$ ), the plants grew properly and purified landfill leachate effectively.

(2) In the low concentration of landfill leachate, the concentration of $\mathrm{COD}, \mathrm{NH}^{3}-\mathrm{N}$ and $\mathrm{TP}$ in Eichhornia crassipes treatments was $63.33 \mathrm{mg} \cdot \mathrm{L}^{-1}, 0.03 \mathrm{mg} \cdot \mathrm{L}^{-1}$ and $0.17 \mathrm{mg}^{\circ} \mathrm{L}^{-1}$ after 24 days. The concentration of COD, $\mathrm{NH}_{3}-\mathrm{N}$ and TP in Pistia stratiotes treatments was $86.67 \mathrm{mg} \cdot \mathrm{L}^{-1}, 0.40 \mathrm{mg} \cdot \mathrm{L}^{-1}$ and $0.51 \mathrm{mg} \cdot \mathrm{L}^{-1}$. Water quality of $\mathrm{F}$ and $\mathrm{D}$ treatments attained national standard of "Pollution control standard for life rubbish landfill (GB16889-2008)".

\section{References}

[1] Y.H. Wei, Y.C. Zhao. Research Evolution of Treatment Technology for Landfill Leachate, Nonferrous Metals Engineering and Research. 2007, 28(2-3): 176-182

[2] J.Chen, L.F. Lai. Treatment Technology for Landfill Leachate in City, Water engineering and scientific. 2007(2): 15-17.

[3] M. Wang, X.M. Yang. Deep Treatment Technology and Analysis of Refuse Percolate, Jiangsu Environmental Science and Technology. 2002, 15(2): 32-34.

[4] G.L. Yuan, Y. Liu. Static Purification of Water-Hyacinths on Wastewater from Intensive Raising Chinese-Turtle. Agro-Environmental Protection. 2001, 20(5): 322-325.

[5] S.Y. Lu, X.C. Jin. Nitrogen removal mechanism of constructed wetland. ACTA ECOLOGICA SINICA, 2006, 26(8): 2670 -2677.

[6] X.H. Zhou, G.X. Wang. Purification Effect of Nitrogen and Phosphorus in Polluted Water of Urban Rivers by Three Landscape Plants. RESEARCH OF ENUIRONMEENTAL SCIENCES. 2009, 22(1): 108-113.

[7] Y.S.Yu, R.K. Deng. Application of Eichhornia Crassipes Aquatic Plant System for Treatment of Sewage from Large-Scale Pig Farm. Agro-Environmental Protection. 2000, 19(5): 301-303. 
[8] Z.Y. Zhang, J.C. Zheng. Role of Eichhornia crassipes uptake in the removal of nitrogen and phosphorus from eutrophic waters. CHINESE JOURNAL OF ECO-AGRICULTURE. 2010, $18(1), 153-157$.

[9] Y.K. Kim, I.R. Huh.Enhancing biological treatability of landfill leachate by chemical oxidation. Environ.Eng. Sci, 1997, 1473-1477. 